\title{
Young people and environmental affordances in urban sustainable development: insights into transport and green and public space in seven cities
}

Sylvia Nissen ${ }^{1,2^{*}}$, Kate Prendergast ${ }^{1,3}$, Midori Aoyagi $^{4}$, Kate Burningham ${ }^{1}$, Mohammad Mehedi Hasan ${ }^{1,3}$, Bronwyn Hayward ${ }^{1,3}$, Tim Jackson ${ }^{1}$, Vimlendu Jha ${ }^{5}$, Helio Mattar ${ }^{6}$, Ingrid Schudel 7 , Sue Venn ${ }^{1}$ and Aya Yoshida ${ }^{4}$

\begin{abstract}
Background: Cities are at the fore of sustainability challenges of the twenty-first century, and many, particularly in Asia and Africa, are predominantly youthful spaces. Understanding young people's experiences in urban environments is therefore important as we strive to achieve both the Sustainable Development Goals and the Paris Agreement. Two amenities identified in the urban Sustainable Development Goal 11, transport and public and green space, are specifically recognised as applying to youth. Yet, there is little analysis that explicitly considers how youth experience these amenities across the Global North and South, and no current measures for understanding progress in youth experiences of green space and transport.

Results: This paper provides a comparative analysis of young people's experiences with local transport and green space in seven diverse urban communities (Christchurch, New Zealand; Dhaka, Bangladesh; Lambeth/London, UK; Makhanda, South Africa; New Delhi, India; São Paulo, Brazil; and Yokohama, Japan). Our study contributes to a growing body of literature that seeks to listen to child and youth perspectives to understand their environmental experiences. We examine the 'affordances' young residents aged 12 to 24 years currently associate with green space and transport amenities. Affordances are defined here as the inter-relationships between what a local environment offers young people and their perceptions and actions. Drawing on focus groups and interviews conducted with 332 young people, we identify five affordances young people associate in relation to transport and public space across these diverse urban settings: (1) social inclusion and belonging; (2) autonomy; (3) physical comfort and security; (4) relaxation and reflection; and (5) health and fitness.

(Continued on next page)
\end{abstract}

\footnotetext{
* Correspondence: sylvia.nissen@lincoln.ac.nz

${ }^{1}$ Centre for the Understanding of Sustainable Prosperity, University of Surrey,

Guildford, UK

${ }^{2}$ Department of Environmental Management, Lincoln University, Lincoln,

New Zealand

Full list of author information is available at the end of the article
}

(c) The Author(s). 2020 Open Access This article is licensed under a Creative Commons Attribution 4.0 International License, which permits use, sharing, adaptation, distribution and reproduction in any medium or format, as long as you give appropriate credit to the original author(s) and the source, provide a link to the Creative Commons licence, and indicate if changes were made. The images or other third party material in this article are included in the article's Creative Commons licence, unless indicated otherwise in a credit line to the material. If material is not included in the article's Creative Commons licence and your intended use is not permitted by statutory regulation or exceeds the permitted use, you will need to obtain permission directly from the copyright holder. To view a copy of this licence, visit http://creativecommons.org/licenses/by/4.0/. 
(Continued from previous page)

Conclusions: The paper contributes to growing interdisciplinary research interest in measuring affordances as a way to advance the Sustainable Development Goals in an urban context. In providing a comparative account of young people's experiences across diverse contexts, our discussion highlights how affordances in relation to transport or public and green space can help understand the multiple interconnections between the well-being of young people and sustainability. In particular, we argue that it is not merely the provision of transport or public and green space that matters, but the nuanced meaning of places and experiences as understood by local communities that needs to be recognised if we are to better support urban youth wellbeing and advance sustainable development goals.

Keywords: Young people, Children, Environmental affordances, Sustainable development, Cities, Qualitative research

\section{Introduction}

Urbanisation is one of the defining sustainability challenges of this century. More than two-thirds of the world's population are expected to live in urban areas by 2050, adding another 2.5 billion people to today's four billion urban residents [1]. Urban areas cover $3 \%$ of the world's land area, but they are sites of approximately $75 \%$ of resource use and carbon dioxide emissions $[2,3]$. The need for urgent far-reaching action to advance sustainable development in the urban context has been recognised in recent international agreements, including Sustainable Development Goal 11 of making cities "inclusive, safe, resilient and sustainable" [4], the New Urban Agenda [5] and the Paris Agreement [6].

Cities are also increasingly youthful places. There are 1.8 billion people between the ages of 10 and 24 years living in urbanised areas, which has been described as "a demographic reality unprecedented in human history" [7]. Of those young people, nearly $90 \%$ of them are resident in the Global South, particularly in Asia and Africa, regions which account for over $90 \%$ of the global growth in the population of cities [8]. By 2030, $60 \%$ of the urban population is projected to be less than 18 years of age [7]. Cities can be crucibles of energy and opportunity for young people, but also sites of resource-intensive lifestyles, as well as deprivation, inequality, and frustration [9-11].

The 1989 UN Convention on the Rights of the Child states that "a child's view must be taken into account in all matters that affect her/him" [12]. Given the importance of young populations to cities, it is concerning that children and youth engagement in urban planning is often only token, with little attempt to understand what cities really mean for children and young people [13, 14]. Most strikingly for the purposes of this paper, only two of the 10 targets and 15 indicators in the urban Sustainable Development Goal 11 specify age related analysis in ways that might measure how urban development specifically impacts children. Moreover, at the time of writing, neither target has effective measurement data. The quality of urban environments have a profound effect on young people's wellbeing [15], life opportunities [16] and agency [17]. However, there is surprisingly little analysis of how young people experience sustainable development in urban communities, especially in lower income countries where the vast majority of young people reside $[18,19]$.

To this end, this paper considers how theories of 'affordances' might help us to understand and measure youth experiences of urban sustainable development. Affordances are defined here as "relations between features of the environment and abilities by individuals and communities to perceive and act" (p. 150) [20, 21]. We report on the urban affordances identified in focus group discussions conducted with 332 young people, aged 12 to 24 years, from seven urban communities of diverse size, in the Global South and Global North. Our focus in this paper is on young people's perspectives and experience of two amenities - transport and green and public space - which are the two areas under the Sustainable Development Goal 11 targets that explicitly specify agerelated significance. Our comparative analysis of young people's experiences highlights how measuring affordances can extend our understanding of how young people's wellbeing might be supported in an urban century.

\section{Young people in urban sustainable development}

Recent international agreements are part of growing attentiveness to cities as loci of interlinked sustainability and development issues. The United Nations 2030 Agenda for Sustainable Development includes a specifically urban Sustainable Development Goal 11 to make cities and human settlements "inclusive, safe, resilient and sustainable" [22]. The New Urban Agenda similarly recognises that if well-planned and well-managed, urbanisation can be a powerful tool for sustainable development for both developing and developed countries. Valencia et al. [23] argue that "seen together", the adoption of Sustainable Development Goals and the New Urban Agenda "represent a historical precedent", marking the first time that the United Nations "has explicitly 
recognised the essential role of subnational entities (i.e. regional and local government institutions) in achieving sustainable development" (p.5).

Cities have also long been recognised as important sites for child and youth development [24, 25]. Young people interact with and experience their environment in different ways to adults, and children and young people are often more dependent on their local environments [26-29]. Some researchers have drawn similarities between the qualities of child-friendly cities and sustainable cities [17, 30]. Frast [31] argues that "by promoting connected, multifunctional, intergenerational and sustainable public spaces for cities, children's infrastructure can generate a substantial range of benefits for all urban citizens" (p. 7). Similarly, Malone [16] suggests "the wellbeing of children and their participation could serve as both a maker and marker of the progress of city or country to meet the challenge of sustainable development" (p. 18).

However, place-based experiences and mobility needs of children and youth are given limited mention in Sustainable Development Goal 11 (Table 1). The indicators for these targets are suggested by Klopp \& Petretta [32] to be "extremely limited", and perhaps better understood as "guides for evaluation not definitive measures of progress on complex issues" (p.95; also Hák [33]). An important consideration is therefore what conceptual approaches can be used to advance Sustainable Development Goal targets in ways that also support child's wellbeing and 'well-living' (or collective experiences of flourishing) [34].

\section{The contribution of the theory of urban affordances to measuring sustainable development goals}

When measuring youth experiences of access to public transport and green space (SDG 11.2. and 11.7), one promising approach is to consider young people's experiences of the affordances of these features of their urban environment. The foundation for affordance literature was Gibson's [35] suggestion that individuals discern diverse possibilities for action in their environments (see

Table 1 Child related indicators in Sustainable Development Goal 11: Make cities and human settlements inclusive, safe, resilient and sustainable (emphasis added)

\begin{tabular}{|c|c|}
\hline Target 11.2 & $\begin{array}{l}\text { By 2030, provide access to safe, affordable, } \\
\text { accessible and sustainable transport systems } \\
\text { for all, improving road safety, notably by } \\
\text { expanding public transport, with special } \\
\text { attention to the needs of those in vulnerable } \\
\text { situations, women, children, persons with } \\
\text { disabilities and older persons. }\end{array}$ \\
\hline Target 11.7 & $\begin{array}{l}\text { By 2030, provide universal access to safe, inclusive } \\
\text { and accessible green and public spaces, in particular } \\
\text { for women and children, older persons and persons } \\
\text { with disabilities [12]. }\end{array}$ \\
\hline
\end{tabular}

extended discussion in [36]). The idea of children's affordances was then developed by Heft $[37,38]$ and has informed environmental psychology [39], technology studies [40], children's geographies [41], environmental education [42], political science and peace and conflict studies [43], and studies of young people's individual and social development [44].

Initially, youth and urban affordances research tended to focus on the functional aspects of the environment, and the opportunities and restrictions local places offer a young person. This approach remains quite prominent within some urban design research (for discussion see [41]). However, subsequent work for example by Clark \& Uzzell [39] and Kyttä [41] developed a more socially, emotionally and culturally driven concept of affordances. Viewed in this way, physical aspects of the environment are seen as the 'building blocks' of subsequent experiences and are best understood through local and indigenous knowledge, social attitudes behaviours, norms and habits (for discussion see Kaaronen [21]).

Affordances from this perspective are not uniform properties of environments. Rather, affordances are the meaningful "relations between abilities to perceive and act, and features of the environment" [20] (p. 150). As Kyttä et al. [45] argues, this socially informed approach helps to break the subject-object dichotomy: an affordance is not simply a characteristic of the environment, nor a characteristic of an individual, but rather something between them. For example, Clark and Uzzell [46] evaluated different local environments for what they can afford residents, including: a place to be active; enjoy; feel safe; avoid others; and meet new people. Egli et al. [47] found large parks, natural spaces and shops were important destinations for children if and when they afford diverse opportunities for socialisation and active and imaginative play.

Examining affordances offers a distinct perspective on the relationship between young people and their local urban environments. Existing accounts of the salience young people give to their urban environment has been criticised for being descriptive rather than conceptually informative, and focusing on the preferences of people as observers rather than advancing a nuanced appreciation as to 'why' those preferences might exist [48]. Affordance theory helps challenge simple descriptive accounts of children's experiences in their environment. Clark and Uzzell [46], for example, note the ways adolescents also attempt to modify and change their environments, to achieve desired developmental goals and opportunities.

Affordance theory can also help identify opportunities for policy interventions or leverage points [21]. Leverage points are here to be understood as "places in the system where a small change could lead to large shift" (p. 146) 
[49] in the system's behaviour [50]. As Kaaronen [21] argues, examining sustainable development through the lens of affordance theory raises a new set of planning questions: "What kinds of affordances do we reinforce, foster and inhibit, and how is this reflected in everyday behaviour patterns?" Other researchers have noted the way opportunities for youth to take advantage of urban affordances can be influenced by social inequality. Murtagh and Murphy [43], for example, note the potentially oppressive effects of segregation and ethnic enclaving, as well as the ways some young people are more advantaged than others with access to resources that can compensate for or enable enjoyment of urban environmental experiences.

However, research also suggests that applying affordance theory effectively requires paying close attention to local experiences, rather than assuming a onesize-fits-all policy approach. As Marcus et al. [51] argue, affordances "cannot be imposed by expertise themselves" but require considering the "meanings of places" as understood by the local community (p. 443). For instance, some researchers have examined how the same physical and virtual environments (like parks or Facebook) can afford different opportunities for individuals (emphasis ours) as a result of intersecting experiences of age [9], gender, ethnicity or race, and socio-economic inequality [52]. But there is surprisingly little close analysis of how affordances emerge and are experienced across differing cultural and ethnic communities [48].

\section{Methods}

\section{Study context}

This paper reports on the urban affordances discussed by 332 young people, aged 12 to 24 years, in seven urban communities of diverse size. This research is part of a larger mixed-methods study, CYCLES (Children and Youth in Cities - Lifestyle Evaluation and Sustainability) funded by the UK Economic and Social Research Council. CYCLES is a study of young people's lives in seven cities: Dhaka (Bangladesh); São Paulo (Brazil); Jagdamba Camp in New Delhi (India); Yokohama (Japan); Christchurch (New Zealand); Makhanda (formerly Grahamstown, South Africa); and the London borough of Lambeth (United Kingdom). The study explores the conditions that enable and constrain young people, aged 12 to 24 years, to live environmentally sustainable and fulfilling lives [53]. The seven cities provide considerable diversity to reflect today's urban world, ranging from large mega-cities to small metropolitan areas, and across the Global North and South.

The CYCLES project examines young people's everyday experiences in a number of domains. For the purposes of this paper our focus is on the affordances young people described in two of these domains: (1) transport; and (2) green and public space. These were selected as the two areas within Sustainable Development Goal 11 that explicitly mention children within the targets (Transport systems/Target 11.2; Public and green space/Target 11.7).

\section{Protocol}

Following on from a desk-based context study [52], a total of 45 focus groups and 32 individual interviews were conducted with young people between November 2017 and September 2018 across seven cities. The focus groups and individual interviews sought to gain in-depth, qualitative insight into the experiences of young people in their diverse local communities, what they value about their lives, and to explore their hopes and fears for the future [54]. Semi-structured discussion was used to ask young people what they liked most about living in their city; their everyday activities and experiences; what they would like to change about where they live; and who can make changes in their community.

The diverse sample comprised 332 participants (54\% male) aged 12 to 24 years (33\% $12-14$ years; 33\% 15-17 years; $32 \%$ 18-24 years), who were recruited through local schools and organisations. Local researchers led the focus group discussions in local languages. Each focus group ran for approximately 45 -min, and included six to eight participants of similar age, socio-economic background, and in some cases the same gender. In addition to focus groups, individual interviews with older youth were undertaken in Yokohama, Dhaka and London where it was difficult to coordinate timetables. All discussions were recorded, transcribed in full and, if needed, translated into English. Each city research partner team complied with their institutional and cultural ethical requirements, and overarching ethical guidelines for CYCLES were developed from the UNICEF guide for Ethical Research Involving Children (ERIC) [55]. Further discussion of these ethical practices is provided in Burningham et al. [54].

\section{Coding and analysis}

Local researchers analysed their transcripts and developed summaries of the key findings in relation to the research questions, as well as identifying issues emerging from their city. Researchers from each city then attended a face-to-face workshop where an inductive approach was used to understand how city level data coding was developed. This coded data was then shared across cities to identify themes that had cultural and social resonance [54]. This allowed us to identify common insights across the cities, while considering their local nuances. This group-based comparative analysis resulted in an initial 
set of research themes, and gave insight into how norms, experiences and assumptions varied between cities [53]. Following the workshop, two coders (SN \& KP) independently coded transcripts from each city relating to transport and green/public space. These codes were then reviewed, synthesised and refined to develop interpretive convergence. Final codes were discussed by authors SN, $\mathrm{KP} \& \mathrm{BH}$. The analysis was then circulated among researchers from each city to validate interpretations of the data and to ensure there was good correspondence between the meta-analysis and local city experiences.

\section{Results}

Independently coding participants' discussions of transport and green space revealed strong resonances between the affordances young people described in relation to these two domains across all seven cities. These were: (1) social inclusion and belonging; (2) autonomy; (3) physical comfort and security; (4) relaxation and reflection; and (5) health and fitness (Table 2). Young people in cities also often identified when these affordances were absent, especially as a result of the intersection of experiences of economic inequality and gender or racial discrimination.

Table 2 Extracts summarising the affordances young people described in relation to transport and green and public space

\begin{tabular}{|c|c|c|c|c|}
\hline \multirow[t]{2}{*}{ Affordance } & \multicolumn{2}{|l|}{ Transport } & \multicolumn{2}{|l|}{ Green / Public Space } \\
\hline & Positive & Negative & Positive & Negative \\
\hline $\begin{array}{l}\text { Social } \\
\text { inclusion }\end{array}$ & $\begin{array}{l}\text { "...getting driven....gives us } \\
\text { a few minutes to catch up" } \\
\text { (James, Christchurch) } \\
\text { "...going by taxi I meet } \\
\text { different people and } \\
\text { characters" (Participant G, } \\
\text { Makhanda) } \\
\text { "I go with my friend....as far } \\
\text { as Yokohama station" } \\
\text { (Participant B1, Yokohama) }\end{array}$ & $\begin{array}{l}\text { "I live on one side of town and } \\
\text { my friends live on the other side } \\
\text { of town" (Greta, Christchurch) } \\
\text { "The quality [of transport] } \\
\text { depends very much on the place } \\
\text { you're going" (Bárbara, São Paulo) }\end{array}$ & $\begin{array}{l}\text { "a group of friends... would go to } \\
\text { the beach." (Eliza, Christchurch) } \\
\text { "[l] Spend time with friends in } \\
\text { playgrounds and parks." (Participant } \\
\text { T, Dhaka) } \\
\text { "Vauxhall Park...it's very nice sociable } \\
\text { area" (Lambeth) }\end{array}$ & $\begin{array}{l}\text { "There is no space for us" } \\
\text { (Participant A, Dhaka) } \\
\text { "there's nothing at the } \\
\text { moment that I can think of } \\
\text { socially that you can do here" } \\
\text { (Lambeth) } \\
\text { "[the security guard] says that } \\
\text { making noise and that we } \\
\text { should leave" (Participant O, } \\
\text { Makhanda) }\end{array}$ \\
\hline Autonomy & $\begin{array}{l}\text { "Biking.... is a fun way to } \\
\text { explore" (Eliza, Christchurch) } \\
\text { "I can just take [the bikes] } \\
\text { and go wherever I want" } \\
\text { (Lambeth) } \\
\text { "The car gives you... } \\
\text { autonomy" (Marcos, São } \\
\text { Paulo) }\end{array}$ & $\begin{array}{l}\text { "I can't drive and you do lose that } \\
\text { element of independence" } \\
\text { (Lambeth) } \\
\text { "My mom won't let me go out } \\
\text { alone" (Marina, São Paulo) } \\
\text { "Women also don't know how to } \\
\text { drive" (Participant 6, Jagdamba } \\
\text { Camp) }\end{array}$ & $\begin{array}{l}\text { "I've been everywhere there is to go } \\
\text { with my friends" (Tom, Christchurch } \\
\text { "I roam around with my friends" } \\
\text { (Participant 1, Jagdamba Camp) } \\
\text { "You can do anything there" } \\
\text { (Lambeth) }\end{array}$ & $\begin{array}{l}\text { "My brother do not allow me } \\
\text { to go outside" (Participant R, } \\
\text { Dhaka) } \\
\text { "[My housemate] doesn't feel } \\
\text { comfortable walking through } \\
\text { that park" (Lambeth) }\end{array}$ \\
\hline $\begin{array}{l}\text { Physical } \\
\text { comfort } \\
\text { and } \\
\text { security }\end{array}$ & $\begin{array}{l}\text { "it makes it safer...having } \\
\text { the bike lanes" (Molly, } \\
\text { Christchurch) } \\
\text { "I use family car because it's } \\
\text { safer" (Participant Y, } \\
\text { Makhanda) } \\
\text { "I get the bus instead...it's } \\
\text { way more pleasant" } \\
\text { (Lambeth) }\end{array}$ & $\begin{array}{l}\text { "I'm often harassed on the bus" } \\
\text { (Participant N, Dhaka) } \\
\text { "At night...there is much } \\
\text { harassment" (Bárbara, São Paulo) } \\
\text { "All of the trains that I use are } \\
\text { crowded" (Participant B5, } \\
\text { Yokohama) }\end{array}$ & $\begin{array}{l}\text { "If I've got nothing to do I'll go down } \\
\text { to the library" (Andrea, Christchurch) } \\
\text { "I feel quite safe walking in the } \\
\text { park... because of the lighting and } \\
\text { the second reason is because there } \\
\text { are normally quite a few people } \\
\text { around there" (Lambeth) }\end{array}$ & $\begin{array}{l}\text { "[We] just need somewhere } \\
\text { warm and enclosed that can } \\
\text { be safe" (Erena, Christchurch) } \\
\text { "if we could have recreational } \\
\text { facilities which are safe [for] } \\
\text { children and youth" } \\
\text { (Participant I, Makhanda) }\end{array}$ \\
\hline $\begin{array}{l}\text { Relaxation } \\
\text { and } \\
\text { reflection }\end{array}$ & $\begin{array}{l}\text { "I enjoy my morning walks } \\
\text { to campus....... listen to } \\
\text { music and just reflect on... } \\
\text { my life" (Participant C, } \\
\text { Makhanda) } \\
\text { "Crossing the river on your } \\
\text { commute" (Lambeth) } \\
\text { "It is quiet...you can listen to } \\
\text { bird sounds, trees, bars } \\
\text { nearby... love it!" (Bruna, } \\
\text { São Paulo) }\end{array}$ & $\begin{array}{l}\text { "It just doesn't feel as nice, low } \\
\text { street lights so they just don't } \\
\text { work as well as the richer better } \\
\text { parts of Christchurch" (Molly, } \\
\text { Christchurch) }\end{array}$ & $\begin{array}{l}\text { "Nature is beautiful, there are lots of } \\
\text { trees here" (Participant R, Dhaka) } \\
\text { "Having this area...it's really nice and } \\
\text { relaxing" (Lambeth) } \\
\text { "we have trees, green grass around } \\
\text { us that is what I love" (Participant G, } \\
\text { Makhanda) }\end{array}$ & $\begin{array}{l}\text { "I have no time to spend in } \\
\text { leisure activities" (Participant } \\
\text { S, Dhaka) } \\
\text { "in the [botanical] gardens } \\
\text { people dump stuff there" } \\
\text { (Participant C, Makhanda) } \\
\text { "while there may be some } \\
\text { greenery in this part of the } \\
\text { city, over my way there's } \\
\text { none at all" (Participant B4, } \\
\text { Yokohama) }\end{array}$ \\
\hline $\begin{array}{l}\text { Health and } \\
\text { fitness }\end{array}$ & $\begin{array}{l}\text { "Usually I go by walk and } \\
\text { rickshaw. Good side of } \\
\text { walking is physical fitness" } \\
\text { (Participant P, Dhaka) } \\
\text { "I enjoy walking a lot as I } \\
\text { get to exercise. Exercise } \\
\text { helps to clear my mind" } \\
\text { (Participant L, Makhanda) } \\
\text { "[biking is] good exercise" } \\
\text { (Yokohama) }\end{array}$ & $\begin{array}{l}\text { "I feel uncomfortable when I ride } \\
\text { a bicycle" (Participant E, Dhaka) } \\
\text { "I am very lazy when it comes to } \\
\text { walking" (Participant O, } \\
\text { Makhanda) } \\
\text { "It'd be great if you could get on } \\
\text { the train with your bicycle" } \\
\text { (Yokohama) }\end{array}$ & $\begin{array}{l}\text { "Playing sports at Hagley Park" } \\
\text { (Spencer, Christchurch) } \\
\text { "I can meet my friend and play } \\
\text { Badminton." (Participant T, Dhaka) } \\
\text { "We play sports like cricket" } \\
\text { (Participant 1, Jagdamba Camp) }\end{array}$ & $\begin{array}{l}\text { "There is a scarcity of } \\
\text { playgrounds here" } \\
\text { (Participant R, Dhaka) } \\
\text { "Only the older ones have } \\
\text { access to [the equipment]" } \\
\text { (Participant A, Makhanda) } \\
\text { "When I go running the air is } \\
\text { so bad I'd start feeling sick" } \\
\text { (Participant A4, Yokohama) }\end{array}$ \\
\hline
\end{tabular}




\section{Social inclusion and belonging}

Both transport and green space were described by the young people across all cities as offering a way to connect with other people and feel a sense of belonging $(n=61)$. In the case of transport, young people said it offered a chance to spend time with friends and family $(n=21)$. For example, in Christchurch, Nashi told us, "I like how I bike to school and back cos I go with my friend cos she lives close and it takes longer so we can talk for longer". Transport could often be the only chance for this connection. In Dhaka, one person explained that "I prefer walking because it is a great opportunity to meet friends. As we can't get anywhere else to meet, I chose to walk with my school friends" (Participant R). In Yokohama, one student (B1) spoke about transport being an important time to "chat with my friend" that they had gone to junior high school with, but no longer attended the same school. Sometimes transport also offered young people "a few minutes to catch up" with family members (James, Christchurch).

Social connection and inclusion was also discussed when young people spoke about green and public spaces $(n=39)$. Young people described "hanging out", "playing", and "wandering around" in green and public spaces with their siblings, parents, and friends. For example, one participant from Dhaka said "[I] spend time with friends in playgrounds and parks and sometimes playing games in these playgrounds" (Participant T). In Lambeth, participants described the community connecting through events held in local parks: "I think they do it every year now, they all come together and have a barbeque and stuff, and it's very good." In addition to parks and playgrounds, young people also spoke of connecting in shops, markets, and libraries. For example, participants from Jagdamba Camp (FG5) told us that young people spend time together "by standing on the roof talking, they go to the park, they tend to meet in the market or near water taps on the streets".

The amenities of transport and green and public space were described by some young people not only as a means to connect with friends, but also to feel included in the wider community. In Makhanda, Participant G explained that "If I am going by taxi I meet different people and characters. I get to hear things that are happening in my town" and another said "what I like ngobamba (about walking) is that you get to see more new people" (Participant A). Having access to free spaces and events were identified as especially important to this belonging. When talking about a nearby park, a young person from Lambeth says "We go there fairly regularly when it's the weekend and we can't afford to go and eat out or do something. We can bring our food and drink to the park instead and spend the day there." In Makhanda, Participant I said they "like living in
[Makhanda] because we have the national arts and science festivals, so we do not need to spend money attending these events in other towns." Similarly, participants from Jagdamba Camp described feeling a sense of "unity during festivals" (Participant 1, FG5).

However, within cities the affordances of transport and green space were experienced differently by marginalised young people $(n=37)$. One challenge was distribution and access to the amenities of public transport and green space, especially in cities marked by inequality. In São Paulo, Bárbara explained "The quality [of transport] depends very much on the place you're going, or on the region you live. In the periphery, it always lacks infrastructure". Similarly, in Christchurch, Grace said "I find that there are some places where there's not a bus stop around anywhere, or like, they aren't really spread out in other places, there's one like around every corner so they're not very well spaced".

Another challenge was accessing non-commercialised places where young people could be together without censure $(n=8)$. Sometimes this exclusion could be explicit, with security guards control of young people's access to parks and recreational facilities. In Dhaka, participants explained that that elders questioned their presence in public space: "When we sat four or more friends they say why you are stupid siting here" (Participant S1); "we need a place where we can hang out and face no comments from other" (Participant S2). In Makhanda, one participant reported that they were told by security guards that "we are making noise and that we should leave" (Participant O). In Christchurch, Hazel told us she wanted: "to have benches and tables for teens to hang out more. It's like an open area where no one can like, um, prohibit them to not get too loud, like in some malls or cafes, because they won't let you hang out there for too long."

\section{Autonomy}

Young people spoke about the importance of being able to explore the city autonomously and as a way "to see all the interesting places" $(n=34)$. This affordance was discussed in relation to a range of forms of transport ( $n=$ 18). In Christchurch, Makhanda and São Paulo, cars were described as offering "independence" and being able to get to places "when I need to". For example, Marcos (São Paulo) said "The car gives you a lot more comfort ... you have autonomy and control everything", while Participant A (Makhanda) explained "Things have changed ever since I got my own car. Every place has become nearer". For some young people this desire for independence was accompanied by aspirations for car ownership. In some conditions, bikes could also be described by some participants as offering the affordance of autonomy. In Christchurch, young people spoke 
about how biking was "our mode of transport for independently getting around", while Participant U (Makhanda) showed us a picture of her bicycle, explaining "it takes me where my heart leads me, I go to town and back with it, it doesn't get tired."

Public space could also afford young people the opportunities to explore and be autonomous $(n=17)$. In postearthquake Christchurch, where many former building spaces have been left vacant, some young people we spoke to said they enjoyed exploring spaces that were always changing and held the possibility for them to "do" something in them, like community gardens. For example, Carol (Christchurch) describes "just going out and discovering more parts of the city." In Jagdamba Camp participants said how they "roam around with my friends" (Participant 1, FG5). Young people also spoke about the sense of freedom access to green and public space can provide. For example, a young person from Lambeth says "you can do anything there".

However, in many cases, young people also expressed concern at a lack of autonomy, particularly over their transport. Many described being frustrated or "angry" that transport lacked predictability. Participants spoke about how "unreliable", "unpredictable", "irregular" or "confusing" transport could be $(n=23)$ :

"In the public bus, I can't keep my time which makes me a late-comer to the office" (Participant N, Dhaka).

"The buses are really unreliable a lot of the time, and like, for me it takes me an hour sometimes to get to school and back each way so, it's really long" (Molly, Christchurch).

"This was one of about three big delays I'd had in that week... none of the trains were running. I had to get a taxi to the station and I missed my train anyway. It was all a bit of a nightmare" (Lambeth).

A particular frustration for many of the young people we spoke to was that even if they had something to go to, they could not guarantee that they could get there. In Makhanda, one participant described a recent experience when she needed to get somewhere "urgently": "the taxi took a long time to get there. It took me an hour to get there I was so angry... we agreed that they are going to drop me off at the corner they actually dropped me at a very far place" (Participant $\mathrm{O}$ ).

Gender discrimination also significantly restricted the autonomy of some young women. For example, In Jagdamba Camp, participants said that "Girls are not usually allowed to go alone" and that "I have to go everywhere with my mother". They also spoke about gender stereotypes associated with women driving, including that "women do not know how to drive" and "do not drive safe". In Dhaka, Participant S said "sometimes when I want to go outside my mom says you have grown enough to go and play outside. I thought my mom is creating discrimination between boys and girls. Actually the society is responsible for this".

Affordability was also a challenge to autonomy. In Makhanda, some young people told us about being excluded from some types of transport because of their price: "what I don't like is when the fuel price goes up the taxi fare also goes up and I'm still a student so I won't always have the means to use a taxi" (Participant A). In Christchurch, Jasmine explained "They need to stop the bus fares going up. Because most families only use the bus because it was cheap and they had no car... But the bus, like, it's dearer and dearer".

\section{Physical comfort and security}

The amenities of transport and public space could also offer young people the affordance of physical comfort and security $(n=21)$. Participants preferred forms of transport were often spoken about as being "safer" or "less stressful" compared to other forms of transport, for instance taking a taxi instead of walking (Makhanda), taking a rickshaw (Dhaka), having particular infrastructure like bike lanes (Christchurch), or good lighting when walking in a park (Lambeth). In two cities, transport was described as a refuge: one participant in Lambeth spoke about a friend who rode public transport when he did not have a place to sleep, and in Christchurch young people in one focus group discussed families without homes living in cars. However, young people also spoke about preferring forms of transport that were more "pleasant", for instance being "less hot and cramped" and "less like you're a rat in a hole" (Lambeth), having air conditioning (Jagdamba Camp; São Paulo), or requiring less effort when "feeling tired" (Dhaka; Christchurch).

Public spaces could also offer comfort and security $(n=4)$. Libraries, in particular, were identified as affording safety and comfort. Erena in Christchurch told us that young people "just need somewhere, like, warm and enclosed that can be safe, that they can just go, and they can sit and talk with their friends, or they can just like play games or something." Andrea (Christchurch) also explained "if I've got nothing to do I'll go down to the library and hang out around there".

More frequently, however, participants in the sample overall spoke about feeling physically insecure in transport and public space. Concern about injury from traffic was most often discussed in connection with safety, especially in Dhaka. Participant R, for example, explained: 
"When I go by rickshaw, they want to have a race with the cars. Accidents occur in this travel time. They go fast in the narrow road. They even do not stop at the intersections. They disobey the traffic rules. I have survived a few times from this kind of terrible journey" (Dhaka).

Concerns about being hit by cars or trucks were also discussed in São Paulo "Bike is very cool, but for sightseeing ... it's dangerous. You can only use it in the park" (Marina). These fears were also present in the much smaller cities, including Makhanda ("When you are going to school you need to be alert every time as cars would use wrong lane avoiding potholes" (Participant L)), and Christchurch ("I've almost been hit by cars so many times that it's not funny" (Jesse)). In some cities, safety concerns included fear of crime. For example, students in Makhanda spoke about not walking alone to school: "When I am coming to school it depends if I have someone to go with if there are there I will walk but if I do not have anyone I will use taxi since I am afraid to walk alone." In three cities, discussion about lack of control in transport also related to feeling unsafe, for example waiting in the dark for an unreliable bus, or being in a rickshaw, bus or taxi where the driver was "careless" or "dangerous".

Young people also spoke about feeling insecure in public spaces. In Dhaka, Jagdamba Camp and Makhanda, in particular, participants spoke about "crime", harassment, substance abuse, and "lack of security" in public spaces. For example, in Dhaka, Participant S2 told us "We are very concerned about the security. A few days ago, [our friend] was killed but police did not take any action against the murderer. Teenage violence is becoming regular here. There are CCTV cameras in the main street, but they are not working." Safety was also raised by several participants in the context of feeling young. In Makhanda, Participant I explained: "I get afraid because there are many things that taxi drivers do and am afraid of because of their actions... They take advantage of people if you are an old person or a young person".

In six of the seven cities, girls in particular expressed concern about their physical safety. In Dhaka, one girl explained "I'm unsafe alone on the bus... I was physically touched by the helper of the bus, and no one protested". Another told us:

"My family is very conservative. I have to think of safety and security. My parents are always in tension when I go outside. The environment is not secured outside on the road and in the park. If the authorities could ensure security, then I can go there. My family does not allow me to go outside" (Dhaka).
In Christchurch, a conversation between girls from one neighbourhood discussed how unsafe they felt "walking in the dark by myself", and that "I feel like there's someone looking at you". A young woman in Lambeth described getting "harassed around here quite often".

Some forms of transport also contributed to physical discomfort $(n=29)$. How young people spoke about discomfort varied between the cities, but included transport conditions that were dusty, dirty and polluted, were overcrowded, or were too hot, cold or wet. In Yokohama, young people spoke with frustration at overcrowding in the trains ("All of the trains that I use are crowded; the Yokohama Line, Keihin Tohoku Line, Tsurumi Line, they're all crowded", B5), and another joked about wanting a "Dokodemo Door", a door that would transport them to wherever they wanted to go, from the children's manga/anime, Doraemon. In Makhanda, young people spoke about disliking being exposed to the weather: "say you are going to church with white shoes or going to school wearing white socks and when cars move they can spit muddy water on you. It will ruin my socks or shoes" (Participant Z). Young people across the cities also spoke about finding transport challenging when they were "exhausted", "tired" or were carrying a heavy load like food.

\section{Relaxation and reflection}

The ability for young people to sit and think about the world and their place in it is only available to some. Young people talked about transport and green and public spaces affording connections with the natural world. In Dhaka, for example, one person talked about how "Nature is beautiful, there are lots of trees here". Other participants spoke about the natural features they value in their city, such as the "beaches", "hills", and "mountains" in Christchurch; the "river" in Lambeth; and "lakes" in Dhaka. In Makhanda young people spoke about enjoying having "nature around with lots of trees and fresh oxygen". Young people from across the cities also appreciated nearby places with "birds", "vegetation", "trees", "green grass", and that were "full of flowers". For example, Bruna from São Paulo tells us: "It is quiet, it looks like countryside. You can listen to bird sounds, trees, bars nearby... I love it!"

For some young people, public space was the only option for these types of retreats. In Dhaka, for example, Participant B spoke of valuing his daily walks in the park because there is a lack of greenery in the city. Transport also afforded some young people connection with the natural world $(n=14)$. In Lambeth, one participant described "Crossing the river on your commute, it's just nice to have a break from all the, like, big buildings all up around you, especially on a nice day when it's blue 
skies and blue water". Others spoke about enjoying walking past flowers or other plants on the side of the road, or looking at the moon. For five participants in three cities, biking, walking or taking the bus was described as a way to contribute to the wellbeing of the natural world by reducing carbon emissions.

Young people also spoke about how inequality in the distribution of and access to public and green space $(n=$ 19). Young people told us how "richer" or "high income" parts of their cities had more playgrounds and nicer parks and facilities. In Yokohama, one participant said "while there may be some greenery in this part of the city, over my way there's none at all. It's got an artificial feeling so I'd like it to become a town with a bit more nature" (B4). For those young people living in lower socio-economic areas of cities, parks could be "far away" and difficult to access. In Christchurch, Molly described how some suburbs "just seem to have like messy roads or like, it just doesn't feel as nice, low street lights so they just don't work as well as the richer better parts of Christchurch." Similarly, in Dhaka, Participant I told us "We have parks in the developed or high income area of Dhaka city. We also need these kinds of parks here. We have young people here, they can play there".

While some participants valued green and public spaces for their connection to nature, others experienced discomfort in these spaces $(n=32)$. In particular, young people described their frustrations with "garbage", "litter", "rubbish" and "waste" in public spaces. In Jagdamba Camp, one young person said, "The place is not hygienic" (Participant 3); in Dhaka, a participant explained how the park is "beautiful but visitors eat and drop food there. So there should be established a dustbin"; and in Makhanda, Participant C said "in the bot (botanical) gardens people dump stuff there". Young people also attributed feelings of discomfort to "hot and cold" weather, "congestion in the playgrounds", "graffiti" and "air pollution". One participant from Yokohama (A4) told us that when she goes running "the air is so bad I'd start feeling sick".

\section{Health and fitness}

Transport and green space also offered young people the opportunity to be active $(n=54)$. In the case of transport, young people spoke about the "health benefits" of getting exercise by walking or biking, including while getting to school or work $(n=22)$. They described the benefits as being not only for physical health, but also for "mental fitness" (Participant R, Dhaka) and for it to be a "way to clear my mind". In Makhanda, Participant $\mathrm{T}$ for example said: "Ever since I started using a bicycle to get around, I've found it to be a huge lifestyle improvement. It ensures some exercise before and after work". In cities with lower levels of air pollution, young people spoke about enjoying having the "wind in your face" (Luna, Christchurch) or "getting out in the fresh air" (Jessie, Christchurch). For some young people, green and public spaces also offered health and fitness $(n=23)$. These young people spoke to us about "walking", "biking", and participating in sports. In Christchurch, Smoothy talks about the nearby hills being "awesome" because "you can walk, ride your bike, and all that stuff".

The infrastructure for young people's health and fitness varied significantly between cities. In relation to transport, there were differences in the quality of footpaths or bike lanes that supported active transport. In some cities, young people spoke about playing organised sports in purpose built spaces. By contrast, in other cities young people explained how they use public spaces, such as graveyards and empty lots, for spontaneous games of "cricket" and "football" with friends.

Yet these spaces were also coming under pressure. Some young people reported that they were excluded from spaces for fitness. In Makhanda, Participant A explained "At Indoor Sports Centre the equipment for gym are limited only the older ones have access to them because they just come and take it from us because we are young", while Participant G told us how we wanted "recreational places with tight security". Privatisation of land also restricted space to play in. In Dhaka, Participant R explained: "I regret not having a playground in my area. If there any open space or plot it becomes occupied by buildings within two or three months. If there any open space someone comes erects buildings. There is a scarcity of playgrounds here".

Young people in some cities also spoke about their opportunities for fitness being restricted by the pressures of education and employment. For example, Participant $\mathrm{S}$ from Dhaka said "We have to spend all day in studying to achieve a good result". Another participant (Participant B, Dhaka) explained, "There is a playground in our colony. Actually, we do not have time for leisure and play. All day we have coaching and school. Only once or twice a week we can play". Similarly, Participant A from Makhanda reflected "When last did I go to the gym? I don't have time anymore".

Gender discrimination was also present in young people's access to health and fitness, which was especially discussed in Dhaka. Participant S explained "when we go for play they said you are no more little to play in the field." Participant A added: "I want to say there should be two playgrounds separately for boys and girls. I had an incident with boys in a playground, so I cannot go there." Participant E (Dhaka) reflected when she was a child she had become "an expert" on riding a bike, but was told as she was growing up by her mother she could not ride. Participant E explained: "I could not understand why she is telling me that. Now I realize that 
everyone stares at me and I feel uncomfortable when I ride a bicycle."

\section{Discussion}

In earlier sections of this paper, we noted the need for conceptual approaches that can be used to advance the Sustainable Development Goal targets for children and youth [32]. Resonating with previous work by Clark \& Uzzell [56] and Egli et al. [45], this study identified how transport systems and public and green spaces can allow important affordances for young people's social inclusion, autonomy, physical comfort and security, relaxation and reflection, and health and fitness. Yet overall, it was striking how many young people across the seven diverse cities felt they were marginalised within urban environments.

The experiences of the young people we spoke to highlight the considerable challenges confronting the provision of sustainable transport and public space in cities. The significance of provision of transport and green and public spaces has been discussed extensively, including in relation to the urban Sustainable Development Goal 11 and its targets $[57,58]$. However, the concept of affordances makes an important additional contribution: that it is not merely the amenities or provision of transport or public and green space that matters, but the human interactions with it and the interconnections it enables with the natural world that need to be measured to understand how we can better support urban youth wellbeing in sustainable ways [21]. Simply providing public transport or green spaces in itself is not enough - and measurement needs to reflect this.

Kaaronen [21] notes that affordances asks an important set of questions for urban sustainable development, including "Are affordances equal for different populations?" (p.6). This question is highly relevant to all the cities in this study. For these young people, affordances were especially influenced by experiences of economic inequality and gender. The distribution of these amenities often varied significantly within cities, with "poorer" areas within cities often reported to have reduced facilities that were of low quality or poorly maintained, and few opportunities for mobility to other parts of the city. Moreover, in all cities, girls and young women were more likely to report feeling unsafe or excluded from transport and in public spaces. These experiences are an important reminder of the significance of inclusiveness in the provision of urban sustainability agendas.

Resonating with previous work $[29,59]$, our findings also draw attention to the alienation and stigmatisation many young people face in all urban spaces as a result of their age. With regard to transport, there were relatively few options for young people's mobility that were inclusive, active and offered independence, security and comfort. Instead, many of the young people we spoke to identified mobility as a process over which they had little control, and which could be a threat to their safety and security. And despite the potential of green and public space for affording social inclusion, the dominant narrative among young people was that "there is no space for us". This age dimension is important. The 12-24 year olds we spoke to felt their age group in particular was overlooked within local planning processes that emphasised children and adults but not necessarily those in between. As Boyden [9] suggests, it is not only early childhood, but also the particular needs of adolescents and young people that must also be considered to advance well-being and sustainable development in an urban century.

These multiple experiences of marginalisation suggest measures that explicitly engage young people's nuanced experiences at the local level are urgently needed within urban sustainable development agendas, including within Target 11.2 and 11.7 of the urban Sustainable Development Goal 11. Cities are increasingly youthful places, and overlooking the perspectives of youth risks progressing 'green' change that does not account for their needs. This oversight is particularly concerning since there appears to be promising alignment between the affordances young people identify and approaches that are low-carbon and more sustainable. This builds on the work of researchers including Malone [11] and Hanssen [60], who emphasise that cities that support individual youth well-being and urban community wellliving (or collective experiences of flourishing) are also cities that are generally more sustainable. In this study, it was notable that low-emissions forms of mobility conducive to planetary wellbeing, such as walking, biking and public transport, were also valued by young people as a means to connect in local environments and with the human and non-human world. The affordances they provide underscore the dense interconnections between the human and planetary wellbeing [61]. Conversely, our study also highlights how this interplay could be disrupted or undermined by income inequality, gender discrimination and urban infrastructure lock-in, that is, the limited scope for alternative forms of mobility restricting opportunities for reflection and engagement with the natural world $[56,57]$.

The synergies between the experiences of the young people in the seven cities - particularly the affordances offered by public transport and green and public space is also suggestive of the utility of the affordances concept in a comparative context. In particular, this comparative perspective within this study helps draw attention to persistent inequality and marginalisation experienced by young people. However, we would also note that this study is a reminder, as others have noted [51, 52], that affordances cannot be assumed from the top-down. In 
relation to transport, for instance, walking to school could vary within and between cities: in some communities walking could be a means for social inclusion, but could also be a matter of insecurity when there was fear of crime; it could be a source of fitness, but also a risk to physical health with traffic accidents or air pollution; and it could be an opportunity for reflection, as well as the only option when young people could not afford anything else, and therefore a restriction on mobility and opportunities. A one-size-fits-all approach to affordances would miss this nuance within localised meanings of places as understood by children and young people.

\section{Conclusion}

In providing an analysis of young people's experiences in seven diverse cities spanning the Global North and Global South, this paper provides an important comparative contribution to analysis of progress towards the Sustainable Development Goal 11 for children and youth in urban environments. In listening to children and young people's perspectives, our study adds support to recent analysis [21, 51] that suggests understanding the nuanced local affordances offered by transport and green and public space is important for understanding child and youth wellbeing and wellbecoming in low-carbon, sustainable ways. It is not enough to merely identify desired pro-sustainability actions and behaviour gaps. New measures of progress could identify local preferences and affordances which resonate with sustainable ways of living and commonly perceived barriers and measure how those barriers are addressed. The paper identified five affordances that these amenities potentially provide for young people: social inclusion and belonging; autonomy; physical comfort and security; relaxation and reflection; and health and fitness. Yet their discussion also highlighted significant challenges for young people in the seven cities, including inequality, gendered insecurity, social exclusion and age-marginalisation.

The analysis presented in this paper is suggestive of the utility of the theory of affordances in a comparative context. It is worth restating that this analysis has only considered the areas covered by the two targets within the Sustainable Development Goal 11 that specify age: transport and green space. These are important amenities for young people, but there remains a wider issue that the priorities and concerns of urban children and young people are given relatively limited explicit attention within Goal 11. There is considerable scope to broaden targets and indicators to include more agerelated analysis to understand what cities mean for children and young people, including in housing, air quality, waste and participatory planning processes. Engaging with their experiences and perspectives is vital as cities transform to meet the sustainability challenges of an urban century.

\section{Acknowledgements}

Special thanks to the research assistants in each city: Kendall Brake; Ashraf Uddin Fahim; Sofia Ferraz; Aakriti Gupta; Md. Tanzid Hossain; Tanvee Kakati; Luisa Leo; Mandilive Matiwane; Lona Musiyiwa; Patience Shawarira; Nuku Tau; and Niwa Ututaonga. Also to Susan Bouterey and Zea Harman for translation and to all our research participants.

\section{Authors' contributions}

SN \& KP independently coded the interview transcripts, and were the major contributors in writing the manuscript. All authors facilitated focus groups or interviews in their cities, identified emerging themes, and read and approved the final manuscript.

\section{Funding}

CYCLES is funded by the ESRC as part of CUSP (The Centre for the Understanding of Sustainable Prosperity) ES/M010163/1.

\section{Availability of data and materials}

Not applicable.

\section{Ethics approval and consent to participate}

Each city research partner team complied with their institutional and cultural ethical requirements, and overarching ethical guidelines for CYCLES were developed from the UNICEF guide for Ethical Research Involving Children (ERIC).

\section{Consent for publication}

Not applicable.

\section{Competing interests}

The authors declare that they have no competing interests.

\section{Author details}

${ }^{1}$ Centre for the Understanding of Sustainable Prosperity, University of Surrey, Guildford, UK. ${ }^{2}$ Department of Environmental Management, Lincoln University, Lincoln, New Zealand. ${ }^{3}$ Department of Political Science and International Relations, University of Canterbury, Christchurch, New Zealand. ${ }^{4}$ National Institute for Environmental Studies, Tsukuba, Japan. ${ }^{5}$ Swechha, New Delhi, India. ${ }^{6}$ Akatu Institute for Conscious Consumption, São Paulo, Brazil. ${ }^{7}$ Rhodes University, Makhanda, South Africa.

Received: 20 November 2019 Accepted: 18 September 2020

Published online: 28 October 2020

\section{References}

1. United Nations. World youth report: youth and the 2030 agenda for sustainable development. New York: United Nations; 2018.

2. UN Environment. Cities and climate change. n.d. https://www. unenvironment.org/explore-topics/resource-efficiency/what-we-do/cities/ cities-and-climate-change. Accessed 17 Jul 2019.

3. UN-Habitat. The state of the worlds cities: Bridging the urban divide. 2012. https://unhabitat.org/books/state-of-the-worlds-cities-20102011-cities-for-allbridging-the-urban-divide/. Accessed 19 June 2019.

4. United Nations. Goal 11: make cities inclusive, safe, resilient and sustainable. 2016. https://www.un.org/sustainabledevelopment/cities/. Accessed 17 Jul 2019.

5. United Nations. New Urban Agenda. 2017. http://habitat3.org/wp-content/ uploads/NUA-English.pdf. Accessed 21 Jul 2019.

6. United Nations. Paris Agreement 2015. https://unfccc.int/sites/default/files/ english_paris_agreement.pdf. Accessed 21 Jul 2019.

7. UN-Habitat. UN-Habitat and youth. 2013. https://www.un.org/youthenvoy/2 013/08/un-habitat-and-youth/. Accessed 19 Jul 2019.

8. United Nations. Sustainable Development Goals: Youth. https:/www.un.org/ sustainabledevelopment/youth/. Accessed 17 Jul 2019.

9. Boyden J. What does it take for young people to be able to contribute to and benefit from the United Nations' sustainable development goals? Z Psychol. 2019;227(2):157-9.

10. Carroll P, Witten K, Kearns R, Donovan P. Kids in the City: Children's use and experiences of urban neighbourhoods in Auckland. N Z J Urban Design. 2015;20(4):417-36 
11. Malone K, Rudner J. Child-friendly and sustainable cities: Exploring global studies on children's freedom, mobility, and risk; 2017. p. 345-70.

12. UNICEF. The United Nations Convention on the Rights of the Child. 1989. https://downloads.unicef.org.uk/wp-content/uploads/2010/05/UNCRC PRESS200910web.pdf?_ga=2.204573008.114353250.1563696356-563603 807.1562213151. Accessed 21 Jul 2019.

13. Derr V, Chawla L, Mintzer M. Placemaking with children and youth: participatory practices for sustainable communities. New York: New Village Press; 2018.

14. Hart R, editor. Stepping back from the ladder: reflections on a model of participatory work with children in participation and learning. Guildford: Springer; 2008.

15. Krefis CA, Augustin M, Schlünzen HK, Oßenbrügge J, Augustin J. How does the urban environment affect health and well-being? A Systematic Review. Urban Sci. 2018;2(1):19-31.

16. Malone K. Children's place encounters: place-based participatory research to design a child-friendly and sustainable urban development. Geographies Glob Issues: Change Threat. 2015;8:1-30.

17. Wolfram M, Borgström S, Farrelly M. Urban transformative capacity: from concept to practice. Ambio. 2019;48:437-48.

18. United Nations Human Settlements Programme. Cities of youth: Cities of prosperity. Nairobi: UN Habitat; 2013. Available from: https://unhabitat.org/ books/cities-of-youth-cities-of-prosperity/.

19. Huijsmans R, George S, Gigengack R, Evers S. Theorising age and generation in development. Eur J Dev Res. 2014;26:163-74.

20. Chemero A. Radical embodied cognitive science. Cambridge: MIT Press; 2009.

21. Kaaronen RO. Affording sustainability: adopting a theory of affordances as a guiding heuristic for environmental policy. Front Psychol. 2017:8:1974.

22. United Nations. Transforming our world: The 2030 Agenda for Sustainable Development 2015. https://sustainabledevelopment.un.org/content/ documents/21252030\%20Agenda\%20for\%20Sustainable\%2 ODevelopment\%20web.pdf. Accessed 21 Jul 2019.

23. Valencia SC, Simon D, Croese S, Nordqvist J, Oloko M, Sharma T, et al. Adapting the sustainable development goals and the new urban agenda to the city level: initial reflections from a comparative research project. Int J Urban Sustainable Dev. 2019;11(1):4-23.

24. UNICEF. Child Friendly Cities Initiative. 2020. https://childfriendlycities.org/. Accessed 6 Jul 2020.

25. UNICEF. Advantage or Paradox: The challenge for children and young people growing up urban. New York: UN; 2019.

26. Morrow V, Crivello G. What is the value of qualitative longitudinal research with children and young people for international development? Int J Soc Res Methodol. 2015;18(3):267-80.

27. Bessell S, Mason J. Putting the pieces in place: children, communities and social capital in Australia. Sydney: The Benevolent Society and NAPCAN; 2014

28. Loebach J, Gilliland J. Neighbourhood play on the endangered list: examining patterns in children's local activity and mobility using GPS monitoring and qualitative GIS. Children's Geographies. 2016;14(5):573-89.

29. Osborne C, Baldwin C, Thomsen D, Woolcock G. The unheard voices of youth in urban planning: using social capital as a theoretical lens in sunshine coast. Aust Children's Geographies. 2016;15(3):349-61.

30. Bjorklund DF, Blasi $\mathrm{CH}$. Child and adolescent development: an integrated approach: Cengage learning; 2011.

31. ARUP. Cities alive. London: ARUP; 2017. https://www.arup.com/perspectives/ publications/research/section/cities-alive-designing-for-urban-childhoods. Accessed 23 Oct 2019

32. Klopp JM, Petretta DL. The urban sustainable development goal: indicators, complexity and the politics of measuring cities. Cities. 2017;63:92-7.

33. Hák T, Janoušková S, Moldan B. Sustainable development goals: a need for relevant indicators. Ecol Indic. 2016;60:565-73.

34. Bruckauf Z, Cook S. Child-centred approach to sustainable development goals in high-income countries: conceptual issues and monitoring approaches. Florence: UNICEF Office of Research - Innocenti; 2019.

35. Gibson J. The theory of affordances. In: Shaw R, Bransford J, editors. Perceiving, acting, and knowing: Toward an ecological psychology. Hillsdale: Erlbaum; 1977. p. 67-82.

36. Chaudhury M, Hinckson E, Badland H, Oliver M. Children's independence and affordances experienced in the context of public open spaces: a study of diverse inner-city and suburban neighbourhoods in Auckland. N Z Children's Geographies. 2017;17(1):49-63.
37. Heft H. Affordances and the body: an intentional analysis of Gibson's ecological approach to visual perception. J Theory Soc Behav. 1989;19(1):130

38. Heft H. Ecological psychology in context: James Gibson, Roger barker and the legacy of William James' radical empiricism. Mahwah: Lawrence Erlbaum Associates; 2001.

39. Clark C, Uzzell DL. The affordances of the home, neighbourhood, school and town Centre for Adolescents. J Environ Psychol. 2002;22(1-2):95-108.

40. Nagy P, Neff G. Imagined Affordance: Reconstructing a keyword for communication Theory. Soc Media + Society. 2015;1(2):1-9.

41. Kyttä M. The extent of children's independent mobility and the number of actualized affordances as criteria for child-friendly environments. J Environ Psychol. 2004;24(2):179-98.

42. Chawla L. Benefits of nature contact for children. J Plan Lit. 2015;30(4):433-52.

43. Murtagh B, Murphy A. Environmental affordances and children in postconflict Belfast. Space Polity. 2011;15(1):65-79.

44. Pedersen S, Bang J. Historicizing affordance theory: a rendezvous between ecological psychology and cultural-historical activity theory. Theory Psychol. 2016;26(6):731-50.

45. Kyttä M, Oliver M, Ikeda E, Ahmadi E, Omiya I, Laatikainen T. Children as urbanites: mapping the affordances and behavior settings of urban environments for Finnish and Japanese children. Children's Geographies. 2018;16(3):319-32.

46. Clark C, Uzzell D. The socio-environmental affordances of adolescents' environments. In: Spencer C, Blades M, editors. Children and their environments: learning, using and designing spaces. Cambridge: Cambridge University Press; 2006.

47. Egli V, Villanueva K, Donnellan N, Mackay L, Forsyth E, Zinn C, et al. Understanding children's neighbourhood destinations: presenting the kidsPoND framework. Children's Geographies. 2019;18(4):1-15.

48. Lennon M, Douglas O, Scott M. Urban green space for health and wellbeing: developing an 'affordances' framework for planning and design. J Urban Des. 2017;22(6):778-95.

49. Meadows DH, Wright D. Thinking in systems: a primer. White River Junction: Chelsea Green Publishing; 2008.

50. Lockton D, Harrison D, Stanton N. Making the user more efficient: design for sustainable behaviour. Int J Sustain Eng. 2008;1(1):3-8.

51. Marcus L, Giusti M, Barthel S. Cognitive affordances in sustainable urbanism: contributions of space syntax and spatial cognition. J Urban Des. 2016;21(4): 439-52.

52. Shirtcliff B. Transformative power of city play: social media and place in a post-affordance world. Cities Health. 2018;3:1-14.

53. Nissen S, Aoyagi M, Burningham K, Hasan MM, Hayward B, Jackson T, et al. Young lives in seven cities: a scoping study for the CYCLES project. Guildford: University of Surrey; 2017.

54. Burningham K, Venn S, Hayward B, Nissen S, Aoyagi M, Hasan MM, et al. Ethics in context: Essential flexibility in an international photo-elicitation project with children and young people. Int J Soc Res Method. 2019; In press.

55. Graham A, Powell M, Taylor N, Anderson D, Fitzgerald R. Ethical research involving children. Florence: UNICEF Office of Research - Innocenti; 2013. http://childethics.com/wp-content/uploads/2013/10/ERIC-compendiumapproved-digital-web.pdf. Accessed 21 Jul 2019.

56. Kyttä M. Children in outdoor contexts. Affordances and independent mobility in the assessment of environmental child friendliness. Helsinki: Helsinki University of Technology; 2008.

57. Hull A, O'Holleran C. Bicycle infrastructure: can good design encourage cycling? Urban. Plann Transport Res. 2014;2(1):369-406.

58. Haaland C, van den Bosch CK. Challenges and strategies for urban greenspace planning in cities undergoing densification: a review. Urban For Urban Green. 2015;14(4):760-71.

59. Chawla L. Growing up in an urbanising world; 2015.

60. Hanssen $\mathrm{G}$. The social sustainable city: how to involve children in designing and planning for urban childhoods? Urban Plan. 2019;4(1):55-66.

61. Cutter-Mackenzie-Knowles A, Malone K, Barratt Hacking E. Research handbook on childhoodnature: assemblages of childhood and nature research. Switzerland: Springer International; 2020.

\section{Publisher's Note}

Springer Nature remains neutral with regard to jurisdictional claims in published maps and institutional affiliations. 